\title{
PENDIDIKAN KARAKTER MELALUI KETELADANAN TGKH. MUHAMMAD ZAINUDDIN ABDUL MAJID: PERSEPSI MAHASISWA CALON GURU
}

\author{
Muhammad Halqi ${ }^{1}$ dan Agus Muliadi ${ }^{2}$ \\ 1Universitas Hamzanwadi Lombok Timur Nusa Tenggara Barat \\ ${ }^{2}$ Universitas Pendidikan Mandalika Mataram Nusa Tenggara Barat \\ email:mhalqi@hamzanwadi.ac.id
}

\begin{abstract}
Abstrak: Penelitian ini bertujuan mengeksplorasi persepsi mahasiswa calon guru matematika tentang pendidikan karakter melalui keteladanan TGKH. Muhammad Zainuddin Abdul Majid. Studi ini merupakan penelitian deskriptif eksploratif, dengan responden 42 mahasiswa calon guru matematika di Universitas Hamzanwadi Lombok Timur, Nusa Tenggara Barat. Instrumen yang digunakan adalah angket tertutup dengan skala likert dan telah divalidasi (validasi ahli). Data penelitian dianalisis secara deskriptif dan statistik inferensial dengan Moderat Regression Analysis (MRA) pada taraf signifikansi 5\% $(\alpha=0,05)$. Hasil studi menunjukkan bahwa: (1) persepsi mahasiswa calon guru matematika tentang pendidkkan karakter melalui keteladanan TGKH. Muhammad Zainudin Abdul Majid dikategorikan Baik; (2) ada pengaruh pengetahuan mahasiswa terhadap persepsi mahasiswa tentang pendidikan karakter melalui keteladanan TGKH. Muhammad Zainuddin Abdul Majid; (3) ada pengaruh pengetahuan mahasiswa dimediasi keaktifan keluarga mahasiswa dalam organisasi NW, keaktifan mahasiswa dalam organisasi NW, dan dukungan perguruan tinggi terhadap persepsi mahasiswa pendidikan karakter melalui keteladanan TGKH. Muhammad Zainuddin Abdul Majid; dan (4) ada peningkatkan pengaruh pengetahuan mahasiswa dimediasi keaktifan keluarga mahasiswa dalam organisasi NW, keaktifan mahasiswa dalam organisasi NW terhadap persepsi mahasiswa.
\end{abstract}

Kata Kunci: pendidikan karakter, keteladanan, persepsi mahasiswa

\section{CHARACTER EDUCATION THROUGH EXEMPLARY OF TGKH MUHAMMAD ZAINUDDIN ABDUL MAJID: PROSPECTIVE TEACHER'S PERCEPTION}

\begin{abstract}
This study aims to explore the perceptions of mathematics' prospective-teachers about character education through exemplary of TGKH Muhammad Zainuddin Abdul Majid. This study is a descriptive exploratory study, in which the respondents were 42 mathematics prospective-teachers at Hamzanwadi University, East Lombok, West Nusa Tenggara. The instrument used was a questionnaire with a likert scale and has been validated (expert validation). The data of research were analyzed descriptively and statistically (inferential statistics) with Moderate Regression Analysis (MRA) at a significance level of $5 \%(\alpha=0.05)$. The results of study show that: (1) the perception of mathematics prospective-teachers about character education through the examplary of TGKH Muhammad Zainuddin Abdul Majid is categorized as "good"; (2) there is an effect of mathematics prospective-teachers' knowledge on the perception of character education through the examplary of TGKH Muhammad Zainuddin Abdul Majid; (3) there is an effect of mathematics prospective-teachers' knowledge mediated by family activeness of mathematics prospective-teachers in the NW organization, the activeness of the mathematics prospective-teachers in the NW organization, and the support of higher education institutions for the perception of character education through the examplary of TGKH Muhammad Zainuddin Abdul Majid; and (4) there is an increase in the effect of mathematics prospectiveteachers' knowledge mediated by family activeness in the NW organization, the activeness of mathematics prospective-teachers in the NW organization on their perceptions.
\end{abstract}

Keywords: character education, exemplary, prospective-teacher's perceptions

\section{PENDAHULUAN}

Mahasiswa merupakan generasimuda pewaris estafet perjuangan bangsa dan pe- mimpin masa depan yang harus memiliki karakter yang khas sesuai dengan tatanan nilai bangsa Indonesia. Karakter generasi 
bangsa menjadi identitas, penanda, dan ciri pembeda dengan bangsa lainnya (Hafizin \& Ihsan, 2018). Membangun karakter generasi muda yang unggul dan berkepribadian menjadi keharusan untuk mempersiapkan keberhasilan mereka pada masa mendatang. Peranan strategis ini diamanatkan dalam Pasal 3 Undang-Undang Nomor 20 Tahun 2003 tentang Sistem Pendidikan Nasional bahwa pendidikan nasional berfungsi mengembangkan kemampuan, membentuk watak, serta membangun peradaban bangsa yang bermartabat dalam rangka mencerdaskan kehidupan bangsa. Pendidikan yang bermartabat bertujuan untuk berkembangnya potensi peserta didik agar menjadi manusia yang beriman dan bertakwa kepada Tuhan Yang Maha Esa, berakhlak mulia, sehat, berilmu, cakap, kreatif, mandiri, menjadi warga negara yang demokratis serta bertanggungjawab (Prasetyo \& Marzuki, 2016; Muzakki, 2017; Aritonang \& Elsap, 2018).

Pelaksanaan pendidikan formal belum berhasil dengan baik dalam membentuk watak insan yang berakhlak mulia. Fakta saat ini mempertontonkan secara terbuka berbagai bentuk fenomena sosial adanya akhlak/karakter pada kalangan muda yang cenderung amoral (Atika, Wakhuyudin \& Fajriyah, 2019), seperti bullying, membolos di waktu sekolah, mencontek, plagiasi, kekerasan, penyalahgunaan narkoba, penggunaan bahasa dan kata-kata gaul yang tidak baku dan cenderung tidak sopan, bermunculan peer-group (geng) yang meresahkan masyarakat, semakin kaburnya pedoman moral baik dan buruk, semakin rendahnya rasa hormat, membudayakan ketidakjujuran, dan cenderung saling curiga dan benci antarsesama (Budiwibowo, 2013; Kurniawan, 2013). Kondisi ini menjelaskan bahwa lembaga pendidikan masih terpesona dan memprioritaskan ca- paian akademik dan melupakan urgensi pembinaan karakter bagi peserta didik. Sistem pendidikan yang mengutamakan aspek kognitif semata, akan berdampak kepada kualitas perkembangan emosional, akhlak, dan etika peserta didik dalam pergaulan sosial (Prasetyo, Marzuki \& Riyanti, 2020).

Pendidikan karakter merupakan solusi terbaik untuk menyelesaikan degradasi karakter (akhlak) pada generasi muda saat ini. Pendidikan karakter harus dilakukan secara koheren pada lembaga pendidikan, lingkungan keluarga, dan sosial masyarakat, untuk mentrasformasi nilai-nilai karakter yang baik kepada generasi muda (Hafizin \& Ihsan, 2018). Pendidikan karakter merupakan upaya yang terencana untuk membentuk peserta didik mengenal, peduli, dan mengimplementasikan nilainilai kebaikan sehingga peserta didik mempunyai akhlak, karakter, etika, dan perilaku insan kamil (Haryanto, 2011). Pendidikan karakter bertujuan mengembangkan nilai-nilai yang membentuk karakter bangsa berdasarkan Pancasila, yaitu: (1) mengembangkan potensi peserta didik agar menjadi manusia berhati baik, berpikiran baik, berperilaku baik; (2) membangun bangsa yang berkarakter Pancasila; (3) mengembangkan potensi warga negara supaya memiliki sikap percaya diri, bangga pada bangsa dan negaranya serta mencintai umat manusia (Prasetyo, Marzuki \& Riyanti, 2020).

Pendidikan karakter di perguruan tinggi dapat dilakukan melalui keteladanan tokoh internal seperti pimpinan, dosen, karyawan, dan teman sebaya, atau tokoh eksternal yang memiliki karismatik dan diidolakan oleh mahasiswa. Hal ini sesuai dengan pendapat Mulyasa (2012) bahwa pendidikan karakter di lembaga pendidikan menekankan pada keteladanan, pencip- 
taan lingkungan, dan pembiasaan. Prasetyo, Marzuki \& Riyanti (2019) menegaskan bahwa peran keteladanan sangat penting atau penentu utama dalam program pembinaan karakter. Karakter yang positif perlu diajarkan dengan perspektif "lakukan seperti yang saya lakukan!" bukan "lakukan seperti saya katakan!” Pendidikan karakter memerlukan keteladanan karakter seseorang sebagai modeling atau contoh yang dapat ditiru dan dicontoh, seperti keteladanan guru dalam lingkungan pendidikan atau tokoh lain yang karismatik dan berakhlak mulia seperti Pahlawan Nasional (Bashir, Bajwa, \& Rana, 2014; Rachman \& Hijran, 2019).

Keteladanan TGKH. Muhammad Zainuddin Abdul Majid sangat relevan sebagai model dalam mendidik karakter mahasiswa di Universitas Hamzanwadi Lombok Timur Nusa Tenggara Barat. Kriteria yang mendasarinya seperti status beliau sebagai pahlawan nasional, ulama karismatik, dan pendiri Nahdlatul Wathan yang memiliki karakter mulia, kealiman, serta jiwa patriotisme dan nasionalisme (Hamdi, 2018). Ketokohan beliau sangat dihormati, dicintai, dan diagung-agungkan masyarakat $\mathrm{Nu}$ sa Tenggara Barat khususnya sampai saat ini setelah 23 tahun beliau wafat. TGKH. Muhammad Zainuddin Abdul Majid juga memiliki mahakarya yaitu "Wasiat Renungan Masa" yang mengandung bait-bait yang bersumber dari ajaran agama Islam tentang nilai-nilai karakter bagi setiap insan (Hafizin \& Ihsan, 2018; Hadisaputra, Yussuf, \& Kasim, 2020) dan relevan dengan pelaksanaan pendidikan karakter khususnya sembilan pilar karakter (Sutjipto, 2011). Sikap mahasiswa untuk meneladani TGKH. Muhammad Zainuddin Abdul Majid dipengaruhi oleh tingkat pengetahuan tentang biografi beliau, yang dapat diperoleh melalui di lingkungan kampus, lingkungan sosial, dan lingkungan keluarga (Suparno, 2018; Aritonang \& Elsap, 2018; Budiyono \& Harmawati, 2017).

Penelitian ini bertujuan untuk mengungkap beberapa kelebihan TGKH. Muhammad Zainuddin Abdul Majid terutama dalam hal akhlak atau karakter mulia untuk diteladani para generasi muda sekarang, terutama para mahasiswa dan calon guru di Universitas Hamzanwadi Lombok Timur Nusa Tenggara Barat. Pengaruh beliau yang cukup besar di tengah masyarakat Muslim di Nusa Tenggara Barat khususnya menjadikan studi ini memiliki manfaat yang besar dalam rangka penguatan pendidikan karakter bagi para pembaca khususnya dan bagi umat Islam umumnya. Penelitian ini juga untuk menegaskan bahwa keteladanan menjadi salah satu metode yang cukup efektif untuk pendidikan karakter.

\section{METODE}

Penelitian ini merupakan penelitian deskriptif eksploratif (Sugiyono, 2017; Arikunto, 2016; Singarimbun \& Sofyan, 2006), untuk mendeskripsikan persepsi mahasiswa calon guru matematika tentang pendidikan karakter melalui keteladanan TGKH. Muhammad Zainuddin Abdul Majid. Responden penelitian ini, yaitu 42 mahasiswa prodi pendidikan matematika Universitas Hanzanwadi Lombok Timur Nusa Tenggara Barat. Responden diperoleh dengan teknik convenience sampling karena mempertimbangkan waktu penelitian dan tingkat aksesibilitas responden dalam mengisi angket secara online pada masa pandemi covid-19 (Fink, 2011).

Instrumen penelitian ini adalah angket tertutup dengan pilihan jawaban menggunakan skala likert (Muliadi, 2020). Angket persepsi disusun mengacu pada indikator pendidikan karakter holistik (sem- 
bilan pilar karakter) yang dikembangkan oleh Megawangi (2016) yaitu mencintai Tuhan dan ciptaan-Nya; kemandirian dan tanggung jawab; kejujuran dan amanah; hormat dan santun; dermawan, suka tolong-menolong, dan gotong-royong; percaya diri dan pekerja keras; kepemimpinan dan keadilan; baik dan rendah hati; serta toleransi, kedamaian, dan kesatuan. Indikator ini dikembangkan dalam sembilan pertanyaan dan divalidasi oleh para pakar (expert) dan dinyatakan valid.

Data penelitian dianalisis menggunakan statistik deskriptif dan statistik inferensial. Analisis deskriptif digunakan untuk mendeskripsikan persepsi mahasiswa tentang pendidikan karakter melalui keteladanan TGKH. Muhammad Zainuddin Abdul Majid. Rata-rata persepsi $(\bar{p})$ dikonversi dalam bentuk kategori berdasarkan Tabel 1 berikut ini.

Tabel 1. Interpretasi Persepsi Mahasiswa

\begin{tabular}{cc}
\hline Rata-rata $(\overline{\boldsymbol{p}})$ & Kriteria \\
\hline $3,51-4,00$ & Sangat Baik \\
$2,51-3,50$ & Baik \\
$1,51-2,50$ & Cukup Baik \\
$1,00-1,50$ & Kurang Baik \\
\hline
\end{tabular}

Statistik inferensial yang digunakan adalah uji Moderat Regression Analysis (MRA) pada taraf signifikansi 5\% $(\alpha=0,05)$ untuk mengetahui (1) pengaruh pengetahuan mahasiswa $(X)$ terhadap persepsi mahasiswa $(Y)$ dengan rumusan hipotesis statistik yaitu $\mathrm{H}_{0}: \mu 1=\mu 2$ (tidak ada pengaruh pengetahuan mahasiswa terhadap persepsi mahasiswa) dan $\mathrm{H}_{1}: \mu 1 \neq \mu 2$ (ada pengaruh pengetahuan mahasiswa terhadap persepsi mahasiswa); (2) pengaruh pengetahuan mahasiswa $(X)$ dimediasi keaktifan keluarga mahasiswa dalam organisasi NW (M1), keaktifan mahasiswa dalam organisasi NW (M2), dan dukungan perguruan tinggi (M3) terhadap persepsi mahasiswa (Y) dengan rumusan hipotesis statistik yaitu $\mathrm{H}_{0}$ : $\mu 1=\mu 2$ (tidak ada pengaruh pengetahuan mahasiswa dimediasi keaktifan keluarga mahasiswa dalam organisasi NW, keaktifan mahasiswa dalam organisasi NW, dan dukungan perguruan tinggi terhadap persepsi mahasiswa) dan $\mathrm{H}_{1}: \mu 1 \neq \mu 2$ (ada pengaruh pengetahuan mahasiswa dimediasi keaktifan keluarga mahasiswa dalam organisasi NW, keaktifan mahasiswa dalam organisasi NW, dan dukungan perguruan tinggi terhadap persepsi mahasiswa). Jika hasil analisis signifikan atau $p$-value uji regresi lebih kecil dari 0,05, maka $\mathrm{H}_{0}$ ditolak dan $\mathrm{H}_{1}$ diterima atau sebaliknya. Adapun model persamaan regresi Cause and Effect Relationships disajikan pada Gambar 1 berikut ini.

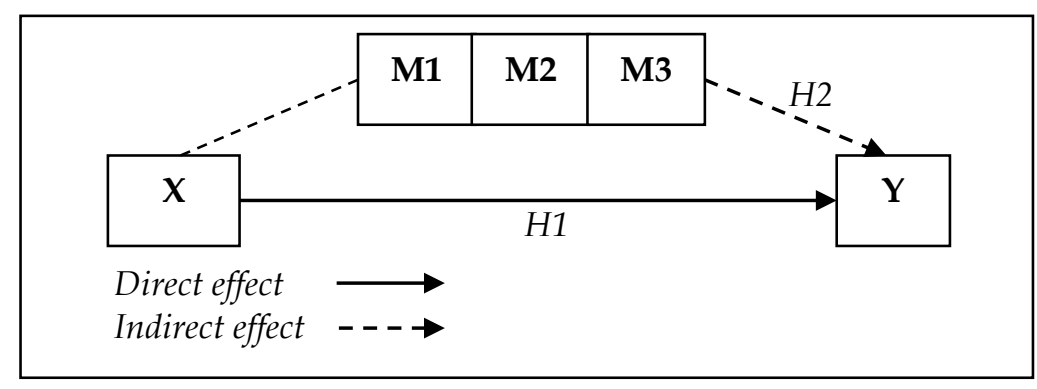

Gambar 1. Model Cause and Effect Relationships

HASIL DAN PEMBAHASAN

Hasil

Deskripsi data persepsi mahasiswa calon guru matematika tentang pendidikan karakter melalui keteladanan TGKH. Muhammad Zainuddin Abdul Majid disajikan pada Tabel 2 berikut ini. 
Tabel 2. Persepsi Mahasiswa tentang Pendidikan Karakter melalui Keteladanan TGKH. Muhammad Zainuddin Abdul Majid

\begin{tabular}{lcccc}
\hline \multicolumn{1}{c}{ Item Pernyataan } & $\boldsymbol{\Sigma}$ Skor & $\mathbf{n}$ & $\overline{\boldsymbol{p}}$ & Kategori \\
\hline Meneladani karakter mencintai Tuhan (Iman \& Taqwa) & 141 & 42 & 3,36 & Baik \\
Meneladani karakter kepemimpinan \& keadilan & 141 & 42 & 3,36 & Baik \\
Meneladani karakter kemandirian \& tanggungjawab & 141 & 42 & 3,36 & Baik \\
Meneladani karakter kejujuran \& amanah & 145 & 42 & 3,45 & Baik \\
Meneladani karakter hormat \& santun & 143 & 42 & 3,40 & Baik \\
Meneladani karakter dermawan, penolong \& kerjasama & 143 & 42 & 3,40 & Baik \\
Meneladani karakter percaya diri \& pekerja keras & 145 & 42 & 3,45 & Baik \\
Meneladani karakter baik \& rendah hati & 143 & 42 & 3,40 & Baik \\
Meneladani karakter toleransi, kedamaian, \& kesatuan & 145 & 42 & 3,45 & Baik \\
\hline
\end{tabular}

Berdasarkan Tabel 2 diketahui bahwa mahasiswa calon guru matematika di Universitas Hamzanwadi meneladani TGKH. Muhammad Zainuddin Abdul Majid dengan Baik $(\bar{p}>3,50)$ dalam mengembangkan karakter pribadi (character building) dengan rincian yaitu: (1) mahasiswa meneladani karakter mencintai Tuhan (Iman dan Takwa) dengan Baik ( $\bar{p}=3,36)$; (2) meneladani karakter kepemimpinan \& keadilan dengan Baik $(\bar{p}=3,36)$; (3) meneladani karakter kemandirian \& tanggung jawab dengan Baik $(\bar{p}>3,36)$; (4) meneladani karakter kejujuran \& amanah dengan Baik $(\bar{p}>$ 3,45); (5) meneladani karakter hormat dan santun dengan Baik $(\bar{p}>3,40)$; (6) meneladani karakter dermawan, penolong, dan berkerja sama dengan Baik $(\bar{p}>3,40)$; (7) meneladani karakter percaya diri dan pekerja keras dengan Baik $(\bar{p}>3,45)$; (8) meneladani karakter baik dan rendah hati dengan Baik ( $\bar{p}>3,40)$; dan (9) meneladani karakter toleransi, kedamaian, dan kesatuan dengan Baik $(\bar{p}>3,45)$.

Model penelitian Cause and Effect Relationships bertujuan untuk mengetahui pengaruh pengetahuan mahasiswa $(X)$ terhadap persepsi mahasiswa (Y); pengaruh pengetahuan mahasiswa dimediasi keaktifan keluarga mahasiswa dalam organisasi NW (M1), keaktifan mahasiswa dalam organisasi NW (M2), dan dukungan perguru- an tinggi (M3) terhadap persepsi mahasiswa (Y), dianalisis menggunakan uji regresi bergandaModerat Regression Analysis (MRA) $(a=0,05)$ dengan tahapan yaitu (1) uji asumsi klasik yaitu uji linieritas dan multikolinieritas; (2) uji-F digunakan untuk mengetahui pengaruh variabel $X$ terhadap variabel $Y$ dan pengaruh variabel $X$ dimediasi variabel M1, M2, dan M3 terhadap variabel Y; (3) uji koefisien determinasi untuk mengetahui persentase sumbangan pengaruh variabel $X$ terhadap $Y$, pengaruh variabel $X$ dimediasi variabel M1, M2, dan M3 terhadap variabel Y. Hasil uji Moderat Regression Analysis (MRA) disajikan secara berturut-turut pada Tabel 3,4,5,6,7 berikut ini.

Tabel 3. Hasil Uji Lineritas dan Multikolinieritas

\begin{tabular}{ccccc}
\hline \multirow{2}{*}{ Model } & \multicolumn{2}{c}{ Deviation from } & \multicolumn{2}{c}{ Collinearity } \\
\cline { 2 - 5 } & $\mathrm{F}$ & Sig. & Tolerance & VIF \\
\hline X-Y & 0,156 & $\mathbf{0 , 6 9 5}$ & 0,244 & $\mathbf{4 , 1 0 0}$ \\
X*M1- $^{*}$ & 0,222 & $\mathbf{0 , 8 8 0}$ & 0,227 & $\mathbf{4 , 4 1 4}$ \\
X$^{*} \mathrm{M} 2-$ & 1,333 & $\mathbf{0 , 2 7 8}$ & 0,174 & $\mathbf{5 , 7 6 0}$ \\
$\mathrm{X}^{*} \mathrm{M} 3-$ & $\mathbf{2 , 3 8 8}$ & $\mathbf{0 , 0 8 4}$ & 0,217 & $\mathbf{4 , 6 1 4}$ \\
\hline
\end{tabular}

Berdasarkan Tabel 3 diketahui bahwa (1) terdapat hubungan yang linier antara pengetahuan dan persepsi mahasiswa $(\mathrm{F}=$ 0,156; $p=0,695>0,05)$, pengetahuan dimediasi keaktifan keluarga dalam organisasi NW dengan persepsi mahasiswa $(F=0,222$; 
$p=0,880>0,05)$, pengetahuan dimediasi keaktifan mahasiswa dalam organisasi NW dengan persepsi mahasiswa $(\mathrm{F}=1,333 ; p=$ $0,278>0,05)$, dan pengetahuan dimediasi dukungan perguruan tinggi dengan persepsi mahasiswa ( $F=2,388 ; p=0,084>$ $0,05)$; (2) tidak terjadi gejala multikolinieritas antarvariabel independen yaitu pengetahuan mahasiswa (VIF $=4,100<10)$, pengetahuan dimediasi keaktifan keluarga dalam organisasi NW (VIF $=4,414<10$ ), pengetahuan dimediasi keaktifan mahasiswa dalam organisasi NW (VIF $=5,760<$ 10), dan pengetahuan dimediasi dukungan perguruan tinggi $(\mathrm{VIF}=4,614<10)$.

Tabel 4. Hasil Uji F Model Persamaan Regresi X terhadap $Y$

\begin{tabular}{lccccc}
\hline & Sum of & $d f$ & Mean & F & Sig. \\
\hline Regression & 2,405 & 1 & 2,405 & $\mathbf{9 , 7 3 4}$ & $\mathbf{0 , 0 0 3}$ \\
Residual & 9,881 & 40 & 0,247 & & \\
Total & 12,286 & 41 & & & \\
\hline
\end{tabular}

Berdasarkan Tabel 4 diketahui bahwa ada pengaruh pengetahuan mahasiswa calon guru matematika terhadap persepsi mahasiswa tentang pendidikan karakter melalui keteladanan TGKH. Muhammad Zainuddin Abdul Majid ( $\mathrm{F}=9,734 ; p=0,000<$ $0,05)$.

Tabel 5. Hasil Uji F Model Persamaan Regresi $X^{*} \mathrm{M} 1, X^{*} \mathrm{M} 2 \quad \& \quad X^{*} \mathrm{M} 3$ terhadap $Y$

\begin{tabular}{lrcccc}
\hline & Sum of & $d f$ & Mean & F & Sig. \\
\hline Regressio & 6,766 & 3 & 1,692 & $\mathbf{1 1 , 3 3}$ & $\mathbf{0 , 0 0}$ \\
Residual & 5,520 & 3 & 0,149 & & \\
Total & 12,286 & 4 & & & \\
\hline
\end{tabular}

Berdasarkan Tabel 5 diketahui bahwa ada pengaruh pengetahuan mahasiswa dimediasi keaktifan keluarga mahasiswa dalam organisasi NW, keaktifan mahasiswa dalam organisasi NW, dan dukungan perguruan tinggi terhadap persepsi maha- siswa calon guru matematika tentang pendidikan karakter melalui keteladanan TGKH. Muhammad Zainuddin Abdul Majid $(F=11,339 ; p=0,000<0,05)$.

\section{Tabel 6. Hasil Uji Koefisien Determinasi} Model X terhadap Y

\begin{tabular}{cccc}
\hline \multicolumn{4}{c}{ Model Summary } \\
\hline $\mathrm{R}$ & $R$ & Adjusted $R$ & Std. Error of the \\
\hline 0,442 & $\mathbf{0 , 1 9 6}$ & 0,176 & 0,49702 \\
\hline
\end{tabular}

Berdasarkan Tabel 6 diketahui bahwa nilai R Square sebesar 0,196 atau 19,6\%. Artinya, bahwa pengetahuan mahasiswa memengaruhi persepsi mahasiswa calon guru matematika tentang pendidikan karakter melalui keteladanan TGKH. Muhammad Zainuddin Abdul Majid sebesar $19,6 \%$ dan sisanya dipengaruhi variabel atau faktor lainnya.

Tabel 7. Hasil Uji Koefisien Determinasi Model $X^{*} M 1, X^{*} M 2, X^{*} M 3$ terhadap $Y$

\begin{tabular}{cccc}
\hline \multicolumn{4}{c}{ Model Summary } \\
\hline $\mathrm{R}$ & $R$ & Adjusted $R$ & Std. Error of the \\
\hline 0,742 & $\mathbf{0 , 5 5 1}$ & 0,502 & 0,38623 \\
\hline
\end{tabular}

Berdasarkan Tabel 7, diketahui bahwa nilai R Square sebesar 0,551 atau 55,1\%. Artinya, bahwa pengetahuan mahasiswa dimediasi keaktifan keluarga dalam organisasi NW, keaktifan mahasiswa dalam organisasi NW, dan dukungan perguruan tinggi mempengaruhi persepsi mahasiswa calon guru matematika tentang pendidikan karakter melalui keteladanan TGKH. Muhammad Zainuddin Abdul Majid sebesar $55,1 \%$ dan sisanya dipengaruhi variabel atau faktor lainnya.

\section{Pembahasan}

Elaborasi hasil penelitian ini menunjukkan bahwa mahasiswa calon guru matematika di Universitas Hamzanwadi me- 
neladani TGKH. Muhammad Zainuddin Abdul Majid dengan Baik $(>3,50)$ dalam mengembangkan karakter pribadi (character building) menjadi seorang insan yang berkarakter (a person of character). Fakta ini membuktikan bahwa mahasiswa calon guru matematika menjadikan keteladanan TGKH. Muhammad Zainuddin Abdul Majid sebagai model dalam mengembangkan karakter. Hal ini sesuai dengan pendapat Prasetyo, Marzuki \& Riyanti (2019) bahwa peran keteladanan sangat penting atau penentu utama dalam program pembinaan karakter. Karakter yang positif perlu diajarkan dengan perspektif "lakukan seperti yang saya lakukan!" bukan "lakukan seperti saya katakan!". Pendidikan karakter memerlukan keteladanan karakter seseorang sebagai modeling atau contoh yang dapat ditiru dan dicontoh, seperti keteladanan guru dalam lingkungan pendidikan formal atau tokoh lainnya yang karismatik dan berakhlak mulia seperti pahlawan nasional (Barahate, 2014; Bashir, Bajwa \& Rana, 2014; Rachman \& Hijran, 2019).

Keteladanan TGKH. Muhammad Zainuddin Abdul Majid bahkan bukan sekedar model, tetapi sebagai inspirasi dan panutan yang senantiasa diteladani oleh mahasiswa calon guru matematika di Universitas Hamzanwadi dalam menginternalisasi dan memanifestasikan nilai-nilai sembilan pilar karakter. Hal ini sesuai dengan kebijakan Pemerintah Republik Indonesia (2010) yang menegaskan bahwa keteladanan bukan sekadar sebagai contoh/teladan bagi peserta didik, melainkan juga sebagai penguat moral bagi peserta didik dalam bersikap dan berperilaku. Hal ini dipertegas dengan pendapat Prasetyo, Marzuki \& Riyanti (2019) dan Harmawati, Abdulkarim \& Rahmat (2016) bahwa keteladanan dalam lingkungan pendidikan menjadi prasyarat utama dalam pembinaan karakter.
Model pembelajaran karakter idealnya dilakukan melalui pembiasaan, keteladanan, dan pembinaan disiplin (Mulyasa, 2012), sehingga keteladanan merupakan teknik terbaik dalam pendidikan karakter (Budiyono \& Harmawati, 2017).

Pendidikan karakter merupakan proses pembinaan perilaku (behaviour) mahasiswa bukan pengetahuan (Lickona, 2012), sehingga untuk dapat diinternalisasi dalam kepribadian, maka harus diteladani bukan diajarkan (Nurchaili, 2010). Pendapat lainnya oleh Nurdiyanto, Resticka \& Marahayu (2018), Suparno (2018), dan Chaerulsyah (2014) bahwa pendidikan karakter membutuhkan keteladanan seseorang sebagai modeling atau contoh yang dapat ditiru dan dicontoh, baik dalam pendidikan formal (kampus) atau lingkungan sekitar (Rachman \& Hijran, 2019). Nurdiyanto, Resticka \& Marahayu (2018) menegaskan bahwa keteladanan merupakan metode influentif dengan keberhasilan yang paling meyakinkan dalam pendidikan untuk membentuk dan mempersiapkan karakter, akhlak, moral, spritual dan kecakapan sosial mahasiswa. Hasil studi ini sesuai dengan hasil studi sebelumnya oleh Taslimah (2010) bahwa keteladanan mempangaruhi pembentukan akhlakul karimah peserta didik dengan kategori tinggi (64\%), sedang (32\%), dan sangat rendah (3\%). Penagruh keteladanan orang tua dikategorikan tinggi (51\%), sedang $(41 \%)$, dan rendah $(6 \%)$. Keteladanan guru pada lembaga pendidikan mempengaruhi dengan baik proses pembangunan karakter peserta didik (Raharjo, 2013; Wulandari, 2015).

Keteladanan TGKH. Muhammad Zainuddin Abdul Majid menjadi model dalam proses pendidikan karakter mahasiswa tentu sangat berdasar dan beralasan yaitu beliau merupakan seorang pahlawan nasional, pejuang bangsa, ulama karismatik dan 
guru dengan kemuliaan karakter, kealiman, jiwa patriotisme dan nasionalisme. Ketokohan beliau lebih dikenal sebagai ulama karismatik dan guru bagi masyarakat Nusa Tenggara Barat (Hamdi, 2018). TGKH. Muhammad Zainuddin Abdul Majid memiliki maharkarya, yaitu Wasiat Renungan Masa yang memiliki relevansi dengan pendidikan karakter karena mengandung ajaran nilai-nilai karakter holistik bagi setiap insan. Wasiat Renungan Masa merupakan mahakarya hasil perenungan (tafakkur), pengalaman empiris (tajribah), dan ilmu pengetahuan yang luas. Hasil studi Hafizin \& Ihsan (2018) menjelaskan bahwa bait-bait dalam Wasiat Renungan Masa mengandung muatan nilai-nilai pendidikan karakter yang bersumber dari ajaran Agama Islam dan selalu mengedepankan kepedulian yang tinggi terhadap nilai kemanusiaan, keagamaan, kebangaaan, kearifan, dan keterbukaan peradaban.

Pendidikan karakter melalui keteladanan TGKH. Muhammad Zainuddin Abdul Majid tentu harus diawali oleh pengetahuan mahasiswa yang cukup baik tentang biografi beliau. Hasil studi ini menjelaskan bahwa pengetahuan mempengaruhi persepsi sebesar 19,6\% ( $R$ Square = $0,196)$. Selanjutnya pengaruh pengetahuan mahasiswa yang dimediasi faktor keaktifan keluarga dalam organisasi NW, keaktifan mahasiswa dalam organisasi NW, dan dukungan Perguruan Tinggi meningkat terhadap persepsi menjadi 55,1\% ( $R$ Square = 0,551). Fakta ini menunjukkan bahwa mahasiswa calon guru matematika meneladani meneladani TGKH. Muhammad Zainuddin Abdul Majid dipengaruhi oleh pengetahuan yang baik tentang biografi TGKH. Muhammad Zainuddin Abdul Majid dan diperkuat dengan mediasi keaktifan keluarga mahasiswa dalam organisasi NW, keaktifan mahasiswa dalam organi- sasi NW, dan dukungan perguruan tinggi. Hal ini sesuai dengan pandapangan Lickona (dalam Prasetyo \& Riyanti, 2019) bahwa pembentukan karakter mulia (good character) harus berawal dari pengetahuan tentang karakter/akhlak (moral khowing), lalu menimbulkan komitmen (niat) terhadap kebaikan (moral feeling), dan akhirnya benar-benar melakukan kebaikan (moral behavior). Oleh sebab itu, setiap meneladani karakter seseorang, kita harus memfilter secara baik menggunakan pengetahuan yang dimiliki (Rachman \& Hijran, 2019).

Pengetahuan yang dimiliki mahasiswa mendapat penguatan dari lingkungan sosial, lingkungan belajar, dan lingkungan keluarga dalam mempengaruhi mahasiswa calon guru matematika untuk meneladani TGKH. Muhammad Zainuddin Abdul Majid (Suparno, 2018; Aritonang \& Elsap, 2018; Budiyono \& Harmawati, 2017). Lingkungan sosial yang dimaksud sangat erat dengan interaksi dan diskusi teman sebaya dalam kelompok tertentu seperti aktivitas mahasiswa dalam kegiatan organisasi Nahdlatul Wathan, akan menimbulkan adanya pembelajaran sebaya (peer teaching) dan dapat meningkatkan pengetahuan tentang TGKH. Muhammad Zainuddin Abdul Majid. Lingkungan belajar tentu terkait proses pendidikan dan pembelajaran serta kegiatan terkait yang diselenggarakan Universitas Hamzanwadi untuk memfasilitasi pengetahuan mahasiswa tentang TGKH. Muhammad Zainuddin Abdul Majid, seperti mata kuliah KeNWan, berHizib, membaca Shalawat Nahdlatain, seminar, buku, dan kegiatan terkait lainnya (Wandi, Musthofa \& Abidin, 2019). Lingkungan keluarga kaitannya dengan pola asuh dan modeling kebiasaan orang tua, karena tidak jarang anak selalu meniru gaya bicara, tingkah laku dan kebiasaan orang tuanya. Oleh sebab itu, aktivitas orang tua mahasiswa dalam 
setiap kegiatan organisasi Nahdlatul Wathan seperti berhizib dan mengoleksi buku dan atribut terkait, akan ditiru dan menjadi sumber pengetahuan mahasiswa tentang TGKH. Muhammad Zainuddin Abdul Majid.

\section{SIMPULAN}

Berdasarkan hasil penelitian dan pembahasan di atas, maka dapat disimpulkan bahwa (1) mahasiswa calon guru matematika meneladani TGKH. Muhammad Zainuddin Abdul Majid dalam pembentukan karakter dikategorikan Baik ( $\bar{p}<3,50)$; (2) ada pengaruh pengetahuan mahasiswa terhadap persepsi mahasiswa tentang pendidikan karakter melalui keteladanan TGKH. Muhammad Zainuddin Abdul Majid ( $\mathrm{F}=$ 9,734; $p=0,000<0,05$ ); (3) ada pengaruh pengetahuan mahasiswa dimediasi keaktifan keluarga mahasiswa dalam organisasi NW, keaktifan mahasiswa dalam organisasi NW, dan dukungan perguruan tinggi terhadap persepsi mahasiswa pendidikan karakter melalui keteladanan TGKH. Muhammad Zainuddin Abdul Majid ( $\mathrm{F}=$ 11,339; $p=0,000<0,05)$; dan (4) pengetahuan mahasiswa mempengaruhi persepsi mahasiswa sebesar $19,6 \%$, sedangkan pengetahuan mahasiswa dimediasi keaktifan keluarga mahasiswa dalam organisasi NW, keaktifan mahasiswa dalam organisasi NW, dan dukungan perguruan tinggi mempengaruhi persepsi mahasiswa meningkat menjadi $55,1 \%$ dan sisanya dipengaruhi variabel atau faktor lainnya.

\section{UCAPAN TERIMA KASIH}

Penelitian ini dapat diselesaikan dengan baik atas bantuan banyak pihak. Secara khusus penulis menyampaikan terima kasih kepada (1) Rektor Universitas Hamzanwadi; (2) Ketua Program Studi Pendi- dikan Matematika, dan (3) para mahasiswa calon guru matematika sebagai responden.

\section{DAFTAR PUSTAKA}

Arikunto. (2016). Prosedur penelitian (suatu pendekatan praktik). Jakarta: Rineka Cipta.

Aritonang, L.A. \& Elsap, D.S. (2018). Analisis faktor yang mempengaruhi peningkatan karakter dan motivasi belajar anak melalui pendidikan non formal (Studi kasus di bimbingan belajar aljabar). Jurnal Pendidikan Nonformal, 13(2), 85-91. DOI: http://dx.doi.org/10.22460/ceria.v2i6.p363369.

Atika, N.T., Wakhuyudin, H. \& Fajriyah, K. (2019). Pelaksanaan penguatan pendidikan karakter membentuk karakter cinta tanah air. Jurnal Mimbar Il$m u, 23(1), 105-113$. DOI: http://dx.doi.org/10.23887/mi.v24i1.17467.

Barahate, Y. S. (2014). Role of a teacher in imparting value-education. Journal of Humanities and Social Science (IOSRJHSS): International Conference on Advances in Engineering $\mathcal{E}$ Technology 2014 (ICAET-2014), 13-15. Retrieved from https:/ / www.iosrjournals.org/iosr-jhss/papers/ICAET-2014/volume-1/4.pdf

Bashir, S., Bajwa, M., \& Rana, S. (2014). Teacher as a role model and its impact on the life of female students. International Journal of Research Granthaalayah, 1(1), 9-20. DOI: https://doi.org/10.5281/zenodo.884561.

Budiwibowo, S. (2013). Membangun pendidikan karakter generasi muda melalui budaya kearifan lokal di era 
global. Premiere Educandum: Jurnal Pendidikan Dasar dan Pembelajaran, 3(1), 39-49. DOI: http://doi.org/10.25273/pe.v3i01.57.

Budiyono \& Harmawati, Y. (2017). Penguatan pendidikan karakter melalui nilai-nilai keteladanan guru dan orang tua pada siswa sekolah dasar. Prosiding Seminar Nasional PPKn, 3(1), 1-10. Retrieved from http://pics.unipma.ac.id/content/download/B0 0911052019040637Prosiding\%204.pdf.

Chaerulsyah, E.M. (2014). Persepsi siswa tentang keteladanan pahlawan nasional untuk meningkatkan semangat kebangsaan. Indonesian Journal of History education, 3(1), 1-5. Retrieved from https://journal.unnes.ac.id/sju/inde x.php/ijhe/article/view/3875.

Fink, A. (2011). How to sample in surveys. In how to sample in surveys (2nd edition). Thousand Oaks, CA: SAGE Publication. Retrieved from https:/ / us.sagepub.com/en-us/nam/how-to-sample-in-surveys/book225416.

Hadisaputra, P., Yussuf, A.B. \& Kasim, T.S.A.B.T. (2020). Karakteristik guru dalam tradisi pendidikan Nahdlatul Wathan, Lombok. Jurnal At-Tafkir, 13 (1), 1-17. DOI: https://doi.org/10.32505/at.v13i1.1441.

Hafizin, K. \& Ihsan, M. (2018). Nilai pendidikan karakter dalam wasiat renungan masa TGKH. Muhammad Zainuddin Abdul Majid. Jurnal Al-Muta'aliyah, 1(3), 19-55. Retrieved from http://ejournal.kopertais4.or.id/sasa mbo/index.php/mutaaliyah/article/ view/2997.
Hamdi, S. (2018). Integrasi budaya, pendidikan, dan politik dalam Dakwah Nahdlatul Wathan (NW) di Lombok: Kajian biografi TGH. Zainuddin Abdul Madjid. Jurnal Sosiologi Walisongo, 2(2), 105-122. DOI: https://doi.org/10.21580/jsw.2018.2.2.2964.

Harmawati, Y., Abdulkarim, A. \& Rahmad. (2016). Kajian nilai budaya tradisi Dieng Culture Festival sebagai kearifan lokal untuk membangun karakter bangsa. Journal of Urban Society's Arts, 3(2), 82-95. DOI: https://doi.org/10.24821/jousa.v3i2.1477

Haryanto. (2011). Pendidikan karakter menurut Ki Hadjar Dewantara. Cakrawala Pendidikan: Jurnal Ilmu Pendidikan (Edisi Khusus Dies Natalis UNY), 30 (1) 15-27. Retrieved from http:/ / staffnew.uny.ac.id/upload/131656343.

Kurniawan, S. (2013). Pendidikan karakter: Konsep \& implementasi secara terpadu di lingkungan keluarga, sekolah, perguruan tinggi, \& masyarakat. Yogyakarta: ArRuzz Media.

Lickona, T. (2012). Mendidik untuk membentuk karakter: Bagaimana sekolah dapat memberikan pendidikan tentang sikap hormat dan bertanggung jawab. Jakarta: PT. Bumi Aksara.

Megawangi, R. (2016). Pendidikan karakter: Solusi yang tepat untuk membangun bangsa (5ed.). Depok: Indonesia Heritage Foundation.

Muliadi, A. (2020). Perbedaan gender dalam sikap entrepreneur mahasiswa pendidikan biologi. Jurnal Ilmiah Mandala Education, 6(2), 329-334. DOI: http://dx.doi.org/10.36312/jisip.v4i3.1208 . 
Mulyasa. (2012). Manajemen pendidikan karakter. Jakarta: Bumi Aksara.

Muzakki. (2017). Peran kepemimpinan kepala sekolah berbasis kearipan lokal sasak dalam peningkatan kedisiplinan kerja guru. EDUCATIO: Jurnal Ilmu Kependidikan, 12(2), 19-30, from http://dx.doi.org/10.29408/edc.v12i 2.1298 .

Nurchaili, (2010). Membentuk karakter siswa melalui keteladanan guru. Jurnal Pendidikan dan Kebudayaan, 16(3), 233244. DOI: https://doi.org/10.24832/jpnk.v16i9.515.

Nurdiyanto, N., Resticka, G.A. \& Marahayu, N.M. (2018). Penerapan nilainilai karakter Jenderal Soedirman melalui implementasi pembelajaran menulis kreatif dan berbicara pada siswa SMP Negeri 2 Banyumas. Jurnal LPPM Universitas Jenderal Soedirman Purwokerto, 8(1), 153-162. Retrieved from http://jurnal.lppm.unsoed.ac.id/ojs/index.php/Prosiding/ article/view/637.

Pemerintah Republik Indonesia. (2010). Kebijakan nasional pembangunan karakter bangsa tahun 2010-2025. Jakarta: Kemdiknas RI.

Prasetyo, D. \& Marzuki. (2016). Pembinaan karakter melalui keteladanan guru Pendidikan Kewarganegaraan di Sekolah Islam Al Azhar Yogyakarta. Jurnal Pendidikan Karakter, 6(2), 215231. DOI: https://doi.org/10.21831/jpk.v6i2.12052.

Prasetyo, D., Marzuki \& Riyanti, D. (2020). Pentingnya pendidikan karakter melalui keteladanan guru. Jurnal Harmony, 4(1), 19-32. Retrieved from https://journal.unnes.ac.id/sju/index.php/harmony/article/view/311 53.

Rachman, F. \& Hijran, M. (2019). Kajian keteladanan dalam memperkuat pendidikan Indonesia. Urecol Proceeding, 5 (1), 998-1003. Retrieved from http://lpp.uad.ac.id/wp-content/uploads/2017/05/175-Fazli_Rachman-9981003.pdf.

Raharjo, A.S. (2013). Pengaruh keteladanan guru dalam interaksi teman sebaya. Jurnal Skripsi. Yogyakarta: Universitas Negeri Yogyakarta.

Singarimbun, M. \& Efendi, S. (2006). Metode penelitian survai (edisi revisi). Jakarta Barat: Pustaka LP3ES Indonesia.

Sugiyono. (2017). Metode penelitian kualitatif, kuantitatif, dan RED. Bandung: Alfabeta.

Suparno. (2018). Analisis faktor-faktor pembentuk karakter smart siswa di sekolah Islam terpadu. Jurnal Pendidikan Karakter, 8(1), 62-73. DOI: https://doi.org/10.21831/ jpk.v8i1.21675.

Sutjipto, (2011). Rintisan pengembangan pendidikan karakter di satuan pendidikan. Jurnal Pendidikan dan Kebudayaan, 17(5), 501-524. DOI: https://doi.org/10.24832/ jpnk.v17i5.45.

Taslimah. (2010). Pengaruh keteladanan orang tua dalam pendidikan agama materi terhadap akhlaqul karimah siswa (Studi kasus di SD Negeri Kecandran 01 Salatiga tahun 2009/ 2010). Skripsi. Salatiga: Sekolah Tinggi Agama Islam Salatiga. 
Wandi, Musthofa, M.A. \& Abidin, Z. (2019). Integrasi, interkoneksi "keislaman, kebangsaan dan Nahdlatul Wathan" perspektif historis dari Nahdlatul Wathan untuk Indonesia. Jurnal Nur El-Islam, 6(2), 1-13. retrieved from https://ejurnal.iaiyasnibungo.ac.id/ index.php/nurelislam/article/view/124.
Wulandari, N.E. (2015). Efektivitas keteladanan guru dalam meningkatkan kesadaran shalat lima waktu siswa kelas VIII di MTs Muhammadiyah Srumbung Magelang Jawa Tenggah. Skripsi. Yogyakarta: Universitas Islam Negeri Sunan Kalijaga. 